\title{
Penile carcinoma in medical poor settings in Cameroon: a case report
}

\section{Abstract}

Penile carcinoma is rare especially in circumcised patient. The authors report and document the first case in Cameroon on a 67 years HIV negative male patient.

Keywords: penile carcinoma, circumcised, human papilloma virus
Volume 3 Issue 3 - 2018

\author{
Zacharie Sando,' Michel Noubom, ${ }^{2}$ Jovanny \\ Tsuala Fouogue, ${ }^{3}$ Jean Joel A Belinga,' Y Ymele \\ Fouelifack ${ }^{4}$ \\ 'Faculty of Medecine and Biomedical sciences, University of \\ Yaounde I, Cameroon \\ ${ }^{2}$ Faculty of medicine and pharmaceutical sciences, University of \\ Dschang, Cameroon \\ ${ }_{3}^{3}$ boouda District Hospital Mbouda, Cameroon \\ ${ }^{4}$ Central Hospital Yaounde, Cameroon
}

\begin{abstract}
Correspondence: Zacharie Sando, Faculty of Medecine an Biomedical sciences, University of Yaounde I, Cameroon, BP 4362,Tel 23767778 704I, Email sandozac@yahoo.fr
\end{abstract}

Received: June 24, 2018 | Published: August 03, 2018

\section{Introduction}

Penile cancer is a rare malignancy. ${ }^{1}$ We here report the first case of penile carcinoma, diagnosed in a medical poor settings in Cameroon with difficult management.

\section{Case presentation}

A 67 years old male, a farmer, non smoker, consulted on the $2^{\text {nd }}$ of November 2016 for a so-called non-healing wound of the penis extending to the pubic area evolving for 09 years. The onset dates back to 2007 with pruritus of the testicles which was followed by a firm outgrowth. He was not circumcised. He consulted a dermatologist in 2009 who removed the outgrowth surgically with an electric scalpel. No histological test was done at the time. The resulting wound was unsuccessfully managed using dressings for four months. Persistence of the pruritus and no-healing wound prompted a second consultation

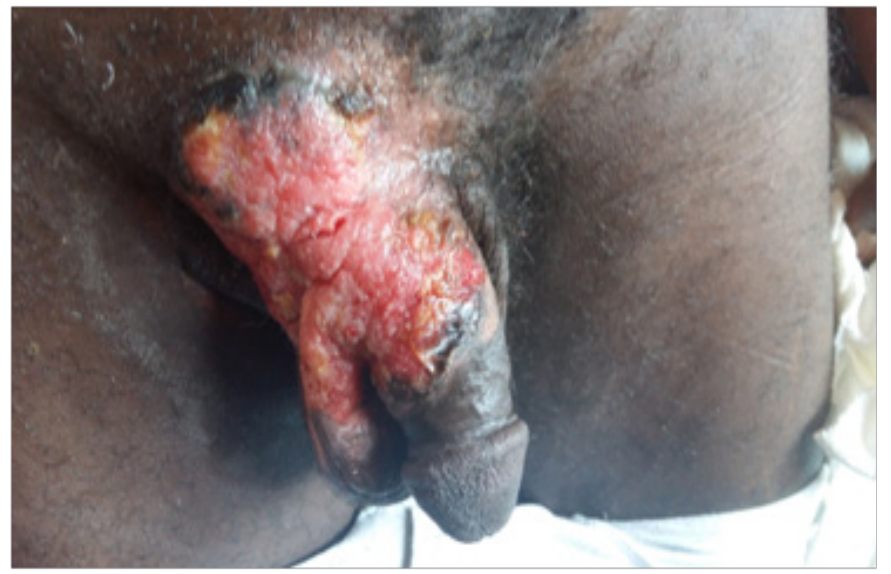

Figure I Macroscopy penile cancer: Note the ulcerating and fungating lesion. at a primary care medical center where this was managed with antibiotics and dressings. Budding of the wound led him to another medical consultation where a work-up ordered with syphilis blood test that was negative. The patient finally consulted at the Baleng Subdivisional medical Center. Clinically there was a large fungating ulcerative and necrotizing lesion of the penis, extending to the pubis (Figure 1). Some firm and fixed bilateral inguinal lymphadenopathy was found on palpation. The full blood count, Blood sugar level was within normal limits. The HIV test was negative. A biopsy of the lesion was performed for histopathology. The tissue specimen was carried to the pathologist at Yaounde Gynaeco-obstetric and pediatric Hospital and diagnosis of invasive squamous cell carcinoma was made (Figure 2) (Figure 3). The search of Human Papilloma virus on the biopsy specimen demonstrated the presence genotype HPV 16. The patient was referred to the oncologist unit of the General Hospital Yaoundé, but did not attend any specialist consultation and is now out of sight.

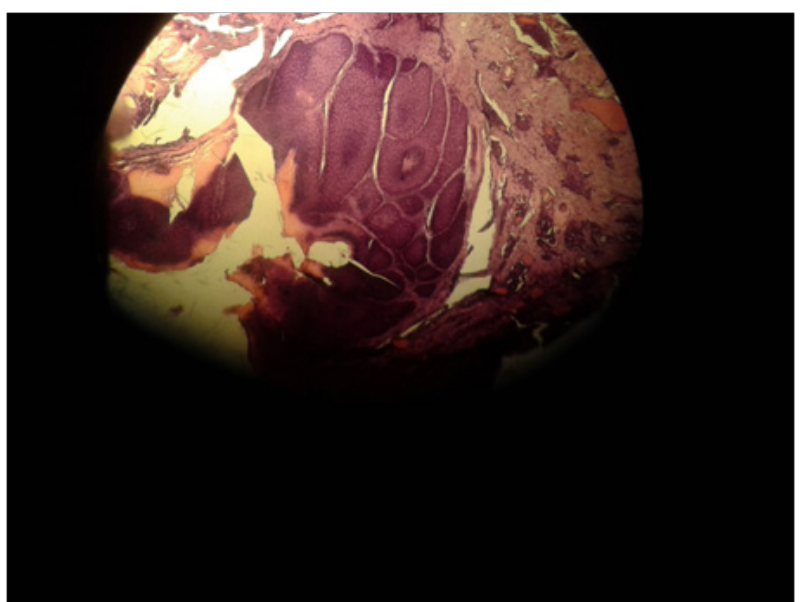

Figure 2 Microscopy of penile squamous cell carcinoma HE x 10: Dysplasia with poushing infiltration of cells. 


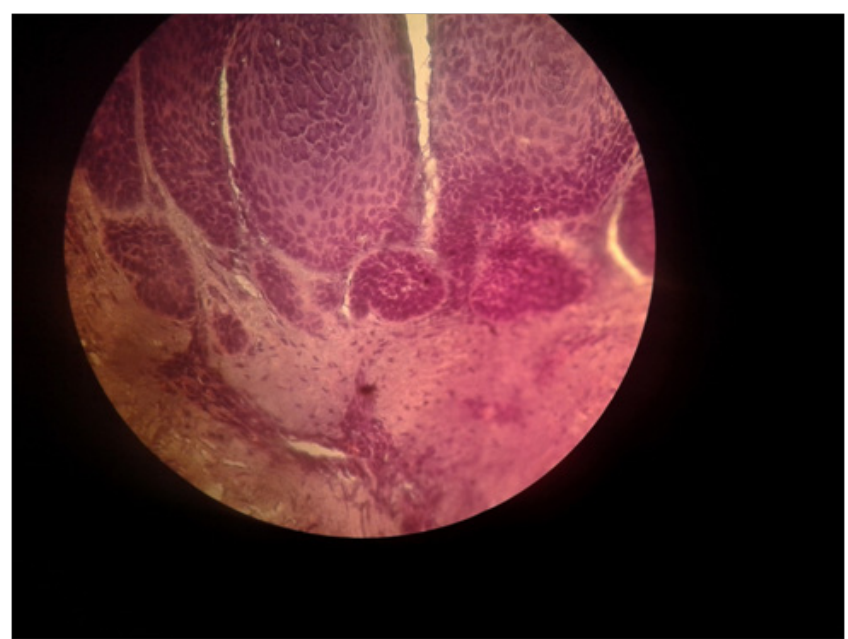

Figure 3 Microscopy of squamous cell carcinoma HE x40: infiltrative nests of cells in the connective tissue.

\section{Discussion}

We described and documented squamous cell carcinoma of a penis, Human papillomavirus virus genotype 16 positive on a $67^{\text {th }}$ years old patient. In contrast to female whom lower genital tract cancers are most frequents in Cameroon, ${ }^{2}$ no case of penile carcinoma has being previously reported in this country of 23 million inhabitants. Mean age at presentation is frequently around 60 years, closed to the 67 years old of our patient at the time of onset. ${ }^{3,4}$ The peak frequency occurs between 60 to 70 years of age. ${ }^{3-5}$

Etiological factors associated with penile cancer are phimosis, chronic inflammatory conditions, especially lichen sclerosis, smoking, ultraviolet irradiation, history of warts, or condylomas and a lack of circumcision as early circumcision decreases the risk $3-5$-fold. ${ }^{6-11}$ None of these conditions could be confirmed from the patient history. Approximately $95 \%$ of penile cancers are squamous cell carcinoma. ${ }^{12-14}$

HPV genotype was found on the biopsy of our patient. This sexually transmitted virus is also involved in female cervical cancer in Cameroon. ${ }^{15}$ Appropriate management of penile cancer is not always applicable in medical poor settings. Moreover, due to some sociocultural barriers patients with penile cancer are more favorable for prompt traditional medical consultation rather than modern medicine.

\section{Conclusion}

We presented the first case of documented squamous cell carcinoma in Cameroon, associated to Human papilloma virus genotype 16 in an elderly patient. It underscores the need for prevention, biopsy and histopathology of suspected lesions for early diagnosis in order to ascertain the diagnosis for appropriate treatment.

\section{Consent}

Written consent for publication of the case was obtained from the patient himself. A copy of this written consent is available for review by the Editor of this journal.

\section{Acknowledgements}

None.

\section{Conflict of interest}

The author declares that they have no competing interests.

\section{References}

1. Bleeker MC, Heideman DA, Snijders PJ, et al. Penile cancer: epidemiology, pathogenesis and prevention. World J Urol. 2009;27(2):141-150.

2. Zacharie Sando ,Tsuala Fouogue Jovanny, Forent Ymele Fouelifack, et al. Profil des cancers gynécologiques et mammaires à Yaoundé - Cameroun. Pan Afr Med J. 2014;17:28.

3. Young RH, Srigley JR, Amin MB. Tumors of the Prostate Gland, Seminal Vesicles, Male Urethra and Penis (fascicle 28). 3rd Edition. AFIP: Washington, DC: 2000.

4. Cubilla AL, Barreto J, Caballero C, et al. Pathologic features of epidermoid carcinoma of the penis. A prospective study of 66 cases. Am J Surg Pathol. $1993 ; 17: 753-763$.

5. Maiche AG. Epidemiological aspects of cancer of the penis in Finland. Eur J Cancer Prev. 1992;1(2):153-158.

6. Hellberg D, Valentin J, Eklund T, et al. Penile cancer: is there an epidemiological role for smoking and sexual behaviour? $\mathrm{Br}$ Med J (Clin Res Ed). 1987;295(6609):1306-1308.

7. Hemminki K, Dong C. Cancer in husbands of cervical cancer patients. Epidemiology. 2000;11(3):347-349.

8. Iversen T, Tretli S, Johansen A, et al. Squamous cell carcinoma of the penis and of the cervix, vulva and vagina in spouses: is there any relationship? An epidemiological study from Norway, 1960-92. BrJ Cancer. 1997;76(5):658-660.

9. Maden C, Sherman KJ, Beckmann AM, et al. History of circumcision, medical conditions, and sexual activity and risk of penile cancer. $J$ Natl Cancer Inst. 1993;85(1):19-24.

10. Nasca MR, Innocenzi D, Micali G. Penile cancer among patients with genital lichen sclerosus. J Am Acad Dermatol. 1999;41(6):911-914.

11. Stern RS. Genital tumors among men with psoriasis exposed to psoralens and ultraviolet A radiation (PUVA) and ultraviolet B radiation. The Photochemotherapy Follow-up Study. $N$ Engl $J$ Med. 1990;322(16):1093-1097.

12. Bah OR, Guirassy S, Diallo AB, et al. Le carcinome épidermoïde de la verge: a propos de deux observations au CHU de Conakry. Afr J Urol. 2007;13(4):291-295.

13. Bastide C, Lesourd A. Épidémiologie des tumeurs malignes du pénis. Prog Urol. 2005;15:797-798.

14. Micali G, Nasca MR, Innocenzi D, Schwartz RA. Penile cancer. $J$ Am Acad Dermatol. 2006;54(3):369-391.

15. Pirek D, Petignat $P$, Vassilakos $P$, et al. Human papillomavirus genotype distribution among Cameroonian women with invasive cervical cancer: a retrospective study. Sex Transm Infect. 2015;91(6):440-444. 